\title{
Pride and Prejudice: Universal Monarchy Discourse and the Peace Negotiations of 1709-1710
}

\author{
David Onnekink
}

In 1725, more than a decade after the Peace of Utrecht, the Frisian politician Sicco van Goslinga, now fifty-nine years old, spoke of 'anti-French principles which after three wars had inspired all of the elder regents.' ${ }^{1}$ The wars against Louis XIV, which had commenced with the Year of Disaster in 1672 and which had lasted until the Peace of Utrecht, had marked a generation of politicians. Anti-French sentiments were deeply entrenched in the national consciousness and had not failed to leave their mark on policymakers.

This in itself is no revelation. We know that ever since the late 1660 s thousands of pamphlets had flooded the Dutch public with anti-French rhetoric, about French pride, deceit, ambition, arrogance, bad religion and corruption. ${ }^{2}$ All these qualities merged into a grand narrative about what has become known as Universal Monarchy. But historians have been less receptive to the fact that such notions also touched the attitude of diplomats and policymakers, even if the Dutch historian Johanna Stork-Penning, who wrote the authoritive study on Dutch negotiations for peace during the War of the Spanish Succession, spoke of the 'distrust of France which showed in all Dutch decisions'; she described it as a 'substantial factor' in the analysis. ${ }^{3}$

And yet, despite this observation, arguably the diplomatic history of this period has normally been studied through the lens of Realism, relying on intricate empirical analyses of day-to-day diplomatic manoeuvres and countermanoeuvres - indeed the very method that Stork-Penning used and which has since then been faithfully followed by other historians studying the War of the Spanish Succession. In effect Dutch historians have all but ignored the impact of Universal Monarchy-discourse on the negotiations. Historians have been fully aware of the pervasiveness of the image of France as a Universal Monarchy, and have understandably located such discourses in such sources

1 Quoted in J.G. Stork-Penning, Het grote werk (Wolters: Groningen, 1958), 5n.

2 Donald Haks, Vaderland \& Vrede (1672-1713). Publiciteit over de Nederlandse Republiek in oor$\log$ (Verloren: Hilversum, 2013), 8.

3 Stork-Penning, Het grote werk, 5 .

(C) KONINKLIJKE BRILL NV, LEIDEN, 2015 | DOI 10.1163/9789004304789_006 
as pamphlets, satirical poems and songs, ${ }^{4}$ but have more or less ignored hardcore diplomatic and political sources such as memorials and correspondence.

The overall purpose of this chapter is to attempt to bridge the methodological gap between cultural and diplomatic historians, to see whether Universal Monarchy discourse in fact pervaded all of these sources, in order to show how policymakers and diplomats did actually work within a wider cultural framework. Too often the compartments of popular culture and diplomacy are presumed to be strictly divided. I take my cue from recent developments in International Relations Theory, in particular from the Danish scholar Lene Hansen. ${ }^{5}$ In building up a case against Realism, she argues that foreign policy should not be explained by analysing a rational decision-making process but by understanding identity discourses, which are often steeped in popular culture. In her words, 'Foreign policies need an account, or a story, of the problems and issue they are trying to address.' ${ }^{6}$ Such a story is built from a 'basic discourse,' a foundational story which is produced and reproduced in cultural and foreign policy texts. Thus one could argue that cultural and political sources are connected through intertextuality. ${ }^{7}$ Hansen operates from the notion of Julia Kristeva that all texts are part of an intertextual web, and she differentiates between explicit textual connections (such as references to other literature) or implicit textual connections (such as comparable concepts or catchphrases like 'clash of civilizations'). ${ }^{8}$ It is the second category of intertextual connections I will be exploring in this chapter, focusing in particular on clusters of keywords and catchphrases. Hansen proposes an intertextual model in which discourses in various kinds of sources can be compared, in order to find out whether a specific discourse was prevalent. ${ }^{9}$ The purpose is to see whether a 'basic discourse' permeated both popular and political sources and thus to see how diplomats were in fact influenced by their cultural context. This also changes our notion on the nature of diplomatic negotiations. Whereas Realist historians assume that the language diplomats use was to describe reality, one could now argue that their language was self-referential, indeed shaped reality by means of the discourse employed. In the words of International Relations

4 E.g. Tony Claydon, 'Protestantism, universal monarchy and Christendom in William's war propaganda, 1689-1697, in Redefining William III: The Impact of the King-Stadholder in International context, ed. E. Mijers and D. Onnekink (Aldershot: Ashgate 2007).

5 Lene Hansen, Security as Practice. Discourse analysis and the Bosnian War (Abingdon: Routledge, 2006).

6 Hansen, Security as Practice, vi.

7 Hansen, Security as Practice, ch. 4.

8 Hansen, Security as Practice, 56-57.

9 Hansen, Security as Practice, 64. 
expert Ken Booth, 'words shape as well as reflect reality', thus underscoring the performativity of diplomatic language. ${ }^{10}$ Such a method would help decompartmentalize the study of international relations, which is now often studied in isolation by cultural, literary and diplomatic historians. Until now, such a method has not been specifically applied to early modern foreign policy.

In order to test this contention I will conduct a short case study into the Franco-Dutch negotiations for peace in 1709 and 1710 and track the spread of Universal Monarchy discourse: the story Dutch politicians needed to address their concerns. It has normally been argued that the talks failed because of essential differences of opinion and a conflict of interest between the Dutch and the French as well as between the Allies themselves. ${ }^{11}$ I will investigate Dutch prejudices against French intentions that hampered the talks, in order to show how identity constructions formed the building blocks of foreign policy discourses and may have thus been more influential than rational differences of opinion. This will be done by a comparative analysis of the discourses used in three categories of sources: public news sources (the Europische Mercurius, a newsbook), official government sources (a resolution by the States General) and confidential political and diplomatic documents (a political memorial and a large number of diplomatic letters). These sources will be matched against a foundational text which generated the 'basic discourse' of Universal Monarchy in the first place, Petrus Valckenier's Verwerd Europa ofte Polityke en Historische Beschrijving der waare Fundamenten en Oorzaken van de Oorlogen en Revolutiën in Europa, voornamentlijk in en omtrent de Nederlanden, sedert den jare 1664, gecauseert door de gepretenteerde universele Monarchie der Franschen ... (1675) (Europe in turmoil, or the Political and Historical description of the true foundations and causes of the wars and revolutions in Europe... caused by the pretended Universal Monarchy of the French). ${ }^{12}$

\section{The 1709-10 Peace Negotiations}

The Dutch negotiations for peace during the War of the Spanish Succession have been researched in detail. ${ }^{13}$ Between 1705 and 1710 a series of bilateral

$10 \quad$ Ken Booth, 'Discussion: a reply to Wallace,' Review of International Studies 23:3 (1997), 371-377, 374.

11 Stork-Penning, Het grote werk.

12 An updated version was published in 1688.

13 Stork-Penning, Het grote werk tracks the negotiations for peace between 1705 and 1710 in detail. See also A.J. Veenendaal, 'The War of the Spanish Succession in Europe,' in The New Cambridge Modern History VI, ed. J. Bromley (Cambridge: Cambridge University 
Franco-Dutch talks took place, which ultimately failed and opened the way for talks between the French and the English that would lead to the Peace of Utrecht. Wedged between their desire for peace, French ambition and conflicts of interests between the Allies, Dutch diplomats were left with very limited options and were ultimately unsuccessful in reaching a settlement. The talks in 1709 took place in several cities in the United Provinces, mainly Woerden near Utrecht, in utter secrecy between the French envoy Pierre Rouille and the Dutch negotiators Willem Buys and Bruno van der Dussen, the pensionaries of Amsterdam and Gouda. The French were extremely anxious to conclude peace and started negotiating on the basis of turning over the whole of the Spanish inheritance to Archduke Charles, if the Allies were willing to provide Philip of Anjou with some compensation. In order to show his willingness, Louis XIV, reportedly crying in humiliation, decided to send his minister marquis de Torcy to The Hague in May 1709. Ultimately, however, the talks failed because the French were unwilling to ratify the preliminaries in June 1709, and war continued.

In March 1710 the talks were resumed by the French diplomats marquis d'Huxelles and Melchior de Polignac and the Dutch negotiators Buys and Van der Dussen in the town of Geertruidenberg. Again the negotiations failed (in July) because of the insistence of the Dutch that Louis help the Allies to remove Philip from the Spanish throne, which he refused. The success of the negotiations hinged on whether Louis would be true to his word in persuading Philip of Anjou to vacate the Spanish throne. Ultimately, the Dutch believed he would not, and Louis refused to put troops at the disposal of the Allies to remove his grandson by force, as the agreement suggested.

Distrust and anti-French prejudice had been feeding Dutch popular political discourse ever since the start of the war. Distrust was a key notion in the Dutch declaration of war in 1702. Whereas the English issued a short and composed statement in which they declared their intention to maintain the balance of power in Europe, the Dutch issued a long and emotional declaration centered on the trauma of 1672 and the threat of Universal Monarchy. ${ }^{14}$ Distrust of French ambition was so ingrained in Dutch political consciousness by 1702 that all of France's actions were interpreted in this light, even future

Press, 1970), 410-445, and David Onnekink and Renger de Bruin, De Vrede van Utrecht (Hilversum: Verloren 2013).

14 Manifest, houdende de redenen waerom de Hoogh Mog. Heeren Staten Generael der Vereenighde Nederlanden genoodsaeckt zijn tegens de koningen van Vranckrijck en Spaigne den Oorlogh te declareren, in dato den achtsten Mey 1702 (The Hague: By Paulus Scheltus, 1702), Knuttel 1476o; A proclamation declaring war against France and Spain (s.a./s.l., 1702). 
ones. Indeed, Louis XIV would later say precisely this in a preamble of the Treaty of Utrecht, in which he stated that 'the distant fear of seeing one day our crown, and that of Spain, upon the head of one and the same Prince,... had been the principal cause of the war, seemed also to lay an insuperable obstacle in the way to peace. ${ }^{15}$ Whereas Louis attributed blame to the Dutch and their unfounded prejudices, Dutch pamphleteers were convinced of French pride and ambition. This notion needed no proof for it was 'undeniable that the King of France, and those of his secret council, since more than fifty years, have made up their minds and deliberated to elevate him as Universal Monarch of Europe,' wrote a pamphleteer in $1702 .{ }^{16}$

\section{Valckenier and Universal Monarchy Discourse}

The foundational text preceding and inspiring Valckenier's book was FranzPaul Lisola's Bouclier D'Estat et de Justice contre le dessein manifestement découvert de la Monarchie Universelle, sous le vain prétexte des prétentions de la reyne de France, published in 1667. It rehashed sixteenth-century notions of the Universal Monarchy of Charles v and applied these to Louis XIV. More specifically, Lisola criticised the aspirations of Louis XIV which had led to the War of Devolution that year. ${ }^{17}$ It was translated into English and Dutch. ${ }^{18}$ Well before the Dutch War of 1672 the concept of France as aspiring for universal monarchy was well known in the Netherlands.

The notion was picked up by Dutch authors, who adapted the concept of Universal Monarchy for a Protestant public (Lisola was a Catholic). ${ }^{19}$ In the United Provinces the ideas of Lisola came to their fullest expression in the work of Petrus Valckenier (1638?-1712?), a lawyer from Amsterdam who

\footnotetext{
15 'Preamble to Peace treaty between France and Spain' (1713), quoted in George Chalmers, A Collection of Treaties Between Great Britain and Other Powers (London: Chalmbers, 1790), 2:56.

16 Het waare intrest van Europa, tot conservatie van hare vryheyt [...] (The Hague: J. Kitto, 1702), Knutel 14800.

17 Horst Lademacher, Phönix aus der Asche?: Politik und Kultur der niederländischen Republik im Europa des 17. Jahrhunderts (Münster: Waxmann 2007), 280.

18 In Dutch: Verdedigingh van staet en gerechtigheyt; tegens het [...] voorneemen der gantsche monarchye, onder d'ydele deckmantel der pretentien [...] van de koningin van Vranckrijck (Amsterdam: J. Vinckel, 1667), Knuttel 9546.

19 Charles-Edouard Levillain, 'The intellectual origins of the Anglo-Dutch alliance 16671677,' Website Le séminaire XVII-XVIII (date of access: 16 July 2014), http://britaix17-18. univ-provence.fr/texte-seance5.php.
} 
later became a diplomat in the Empire. His extensive Verwerd Europa [Europe in turmoil] (1675) was published during the Franco-Dutch war. It was an impressive, one-thousand-page study of the history and nature of French universal monarchy. It tracked French history up to the reign of Louis XIV and provided a theoretical framework of states, interests and international relations. It built up to the second part of the book, which focused on the troubles in Europe. The last part was a narrative of the Franco-Dutch war, detailing the events and the problems within the Dutch Republic. ${ }^{20}$

Valckenier builds his case on the conceptual cornerstone of universal monarchy. The trouble in Europe, he states in the title of his book, is 'caused by the pretended Universal Monarchy of the French'. ${ }^{21}$ He does attribute part of the cause to Louis, to be sure, but the root problem goes deeper. There is a reason the title speaks of 'the French,' rather than the King of France, since Valckenier believes pride and aggrandizement to be a feature of Frenchness. The fifthcentury king Clodius, nick-named Long-Hair on account of wearing ritualized long hair, did so, like all the Franks, Valckenier argues, 'as a sign of their nobility and freedom, which is the reason why all the people they conquered were forced to shave and cut off their beards.'. ${ }^{22}$ Along with the French in general, the French nobility is culpable. They have been made great by Huge Capet, the founder of the French monarchy and have even received 'crowns on the head'. The great houses have become powerful and 'aspired to a higher step of state and dignity' in search of which they 'waged war against one another or against the kings. ${ }^{23}$

Conquest seems typical of the French, as Valckenier described how 'afterwards these Franks under Clodoveus (Clovius) not only submitted the Romans, Goths and Burgundians in the whole of Gaul, but on top of that also won against the Alemans... and conquered everything between the Alps and the Pyrenees, up to Rhine and sea. ${ }^{24}$ Valckenier is not necessarily critical of these

$20 \quad$ Valckenier, Verwerd Europa.

21 Valckenier, Verwerd Europa.

22 'tot een teeken van haaren Edeldom en Vryheyt, om welke reeden sy ook alle Volkeren, die sy overwonnen, dwongen haar haer en baarden af te scheeren', Valckenier, Verwerd Europa, 30.

23 'Kroon op 't hooft', 'altijd aspireerden na hoger trap van Staat en Digniteyt, en daarom de een tegens de ander, ofwel tegens de Koningen selfs oorloogden', Valckenier, Verwerd Europa, 54.

24 'Naderhand hebben dese Franken onder de Regeeringe van Clodoveus niet alleen geheel Gallien, den Romeynen, Gotten en Bourgondiens ontweldigt, maar daar en boven noch overwonnen de Allemannen by Sulpich en verovert al watter leyt van de Alpes en Pireneèn tot aan den Rijn en Zee', Valckenier, Verwerd Europa, 30. 
wars; indeed, he speaks approvingly of Charles Martel who 'has 'triumphantly won against the Saxons and West-Goths' and in a battle 'cut down the Saracens who had invaded France.'. ${ }^{25}$ He admires Charlemagne for 'achieving victory over the Brittons, Danes and Normans in France. ${ }^{26}$ However, implicitly the warlike nature of the Franks is criticized when he writes that 'Clodius invaded the Netherlands, ${ }^{27}$ thus foreshadowing the evil things to come.

Arguably, by building a genealogy of wars, Valckenier points to the warmongering nature of the French, which was also proved by the sons of Louis the Pious, 'who waged amongst each other such bloody and terrible wars' to divide the empire. ${ }^{28}$ Louis XI 'took' the Duchy of Burgundy ${ }^{29}$ while Charles viII 'waged prolongued wars' with Aragon after $1494 .{ }^{30}$ With the death of Francis I 'the flame of war was not extinguished but rekindled by Henry II' ${ }^{31}$ He speaks of the 'long years of domestic wars against the Huguenots' 32 in the late sixteenth century and notes that the murder of Henry IV in 1610 'again kindled lamentable flames of war'. ${ }^{33}$ The 1620 s saw 'domestic wars.' ${ }^{34}$ Valckenier concludes that 'the French from ancient times have been of such a restless and moveable spirit... that they do not live in peace, but are always inclined to war, both foreign and domestic..35

Although Valckenier is not necessarily negative about the wars of the French, indeed he praises Martel for having safeguarded Europe from the Saracens, the narrative tends to be highly critical of the bloodthirsty nature of the French in general and the nobility in particular. The pairing of pride and war is obvious

25 'want hy de Saxen en West-Gotten triumphantelijk heeft overwonnen en van de Saracenen die Vrankrijk invadeerden, in een Veld-slag terneder gemaakt', Valckenier, Verwerd Europa, $31-32$.

26 'de Britten, Deenen en Noormannen in Vrankrijk overwonnen', Valckenier, Verwerd Europa, 32 .

27 'invadeerde de Nederlanden', Valckenier, Verwerd Europa, 3o. He refers to the Spanish Netherlands, though.

28 'sulke bloedige ende affchrikkelyke oorlogen gevoert', Valckenier, Verwerd Europa, 34.

29 'ingenomen', Valckenier, Verwerd Europa, 41.

$30 \quad$ 'langduyrige Oorlogen', Valckenier, Verwerd Europa, 42.

31 'is dese Oorlogs-vlam niet uytgeblust, maar voort gestookt door Hendrik II', Valckenier, Verwerd Europa, 44.

32 'lange jaaren door de inlandse oorlogen tegens de Hugenoten', Valckenier, Verwerd Europa, $5^{0 .}$

33 'jammerlyke Oorlogs-vlammen', Valckenier, Verwerd Europa, 51.

34 'inheemse oorloogen', Valckenier, Verwerd Europa, 51.

35 'daarenboven zijn de Fransche van outs geweest van sulken beweeglyken en onrustigen geest, dat sy noyt konden stil zijn, noch vreedsaam leven, maar altijd inclineeren tot Buyten en Binnen-landse Oorlogen', Valckenier, Verwerd Europa, 55 . 
in his narrative since it is the proud Franks who insisted on visibly humiliating the people they conquered. It is thus when the Franks tend to connect their warlike successes with pride that things go terribly wrong. For Pippin also 'submitted' the Kingdom of Lombards, 'waged war' against the Saxons for thirtythree years and finally conquered them. ${ }^{36}$

The word 'overheersen' cannot be translated into English; it literally means 'overrule' and comes closest to 'subjugate' or 'dominate'. According to the early modern dictionary of Dutch, it means to rule 'but with the connotation that it is against the will of the subjects'. ${ }^{37}$ Hence the French kings were determined 'to govern' over parliaments and nobility. ${ }^{38}$ It is thus the combination of bloodthirst and pride that makes the French dangerous. Throughout the narrative Valckenier gives plenty of examples in which the French kings seek 'domination' (overheersing or heerschappij). This was what the early French kings had sought. For instance, Charlemagne, 'after he had gained such a great reign, as never a French king before him,' re-established the Roman Empire in 800.39 This connection with the empire is important, as Valckenier suggests it is the aim of the French, regarding themselves as the oldest Christian kingdom as well as the foremost kingdom, to claim the imperial crown based on their superiority to all other kings. ${ }^{40}$

The lust to rule pervades most of the actions of the early French (Frankish and Merovingian) kings. Valckenier approves of Martel's inherent humility when he 'refused to accept the title of King which he was offered' ${ }^{41}$ But he was the exception. Important again is the usurpous tendency of many of the French kings. Valckenier tends to be critical when he discusses the reign of the Merovingian 'court chamberlains, which gained full royal power, except for the title and the crown'. ${ }^{42}$ Most notably the founder of the modern kingdom, Huge Capet, 'who placed himself in the possession of the Realm in 987

36 'ontweldigt', 'beoorloogt', 'overheert', Valckenier, Verwerd Europa, 32.

37 'overheersen', reference in Woordenboek der Nederlandsche taal (Instituut voor Nederlandse lexicologie), http://gtb.inl.nl.

38 'te gouverneeren', Valckenier, Verwerd Europa, 41.

39 'Na dat hy sulken grooten heerschappye hem hadde verworven als noyt eenig Fransche Koning voor of naar hem heeft gehad', Valckenier, Verwerd Europa, $3^{2}$.

40 Valckenier, Verwerd Europa, 63.

41 'dat hy refuseerden te accepteeren den Titul van Koning, die hem wierde geoffereert', Valckenier, Verwerd Europa, 32.

42 'dewelke metter tijd aan haar kreegen de geheele Koninklyke macht, behalven den Titul en de Kroon', Valckenier, Verwerd Europa, 31. 
with general permission from the Grandes in France,43 thus underscoring the ambiguity of his claims. In fact, the ambiguity is emphasized by mentioning that the Dukes of Lorraine regard the French kings after Capet 'as illegal possessors and usurpers, of which the present king Louis XIV is one.'44

Despite their usurpous claim to the throne, Valckenier explains how they aspire to the imperial crown; 'the great power and riches have led the French kings to lift themselves to such heights... that they pretend... to precede the Roman Emperor in rank'45 They claim precedence because 'the French boast that their realm had become Christian before Spain' and 'that their title of most Christian king supersedes all others, as the sun does the stars'. 46 This claim has now begun to become reality as from the time of Cardinal Richelieu 'the French have tried to obtain Universal Monarchy, never doubting that they would surely get it'.47 And Valckenier speaks of the 'French pretence' on the Roman Empire. ${ }^{48}$ Their arrogance knows no boundaries for 'they were not afraid to say in public that their kingdom would last forever, but also would dominate over all the realms and lands of the world. ${ }^{49}$ As such they even challenged God himself, 'for it is only known to God, and in his power.'50 Valckenier also explains that Louis XIV, 'arrogantly' nicknamed 'the little god,' is ambitious because of his successes. "The prosperity made him inflated and ambitious, so that he had no other design as to make him master of the world, and ... universal monarch'. ${ }^{51}$ Valckenier then repeatedly speaks of 'ambitious

43 'de possessie van 't Rijk, daar in sich Hugo Capet sette in 't jaar 987, met gemeene toestemminge van alle de Grooten in Vrankrijk', Valckenier, Verwerd Europa, 35.

44 'voor onwettige besitters en Usurpateurs gehouden, waar uyt desen noch regeerende Koning Louis de XIV mede een is', Valckenier, Verwerd Europa, 35.

45 'Door dese groote macht en rykdom hebben haar de Fransche Koningen so hoog verheven, dat sy daar door... pretendeeren... den Roomschen Keyser in de rang voor te gaan', Valckenier, Verwerd Europa, 63.

46 'dat haaren Titul van Alder-Christelijke so verre alle andere overtreft, als de Son de Sterren', Valckenier, Verwerd Europa, 63.

47 'hebbende Fransen beginnen te staan na de Universeele Monarchie, niet twijfelende of sy souden die seekerlijk verkrygen', Valckenier, Verwerd Europa, $5^{2}$.

48 'Fransche pretensie', Valckenier, Verwerd Europa, $5^{2}$.

49 'schaamden sy haar niet openbaarlijk te seggen, als dat haar Koninkrijk niet alleen altijd soude duyren, maar ook noch verkrygen de Heerschappye over alle de Rijken en Landen van de geheele Wereld', Valckenier, Verwerd Europa, $5^{2}$.

5o 'dat God alleen bekent, en in sijne macht alleen stond', Valckenier, Verwerd Europa, $5^{2}$.

$5^{1}$ 'Desen voorspoet maakt hem so opgeblaasen en ambitieus, dat hy geen ander oogmerk heeft, als hem alleen te maken sulken Meester van de Wereld, en sulken Universelen Monarch', Valckenier, Verwerd Europa, 131. 
oppressor,'52 Louis's 'ambition, 53 his 'ambitious designs' 54 and his 'lust for dominion and ambition, 55 which was the root cause for the wars he waged against the Dutch. ${ }^{56}$ The French 'verhovaardigen' (an archaic verb meaning 'to act haughtily') themselves. ${ }^{57}$ Valckenier speaks of the 'fabricated pretext' that the French have a right to the imperial throne. ${ }^{58}$ As such the king of France has 'climbed to the highest rung of his overmacht ${ }^{59}$ This word 'overmacht' (literally: over might) can also not be translated but suggests dominance, the power he has is larger than that of his opponents so that he can subject them. Lastly, Valckenier refers to the 'tyrannical nature' of the French to underscore their design to subject the nations of Europe. ${ }^{60}$ This is also referred to in a poem in the introduction of the book by B. Vollenhove, who speaks of the 'French suppression. ${ }^{61}$

Lastly, in addition to the warmongering nature and haughtiness, Valckenier refers to France's 'ambitious designs, sinister political maxims, strange intrigues and corrupt activities at all the courts of the Christian world'. ${ }^{62}$ Indeed, along with warmongering, the French try to achieve their usurpous goal by cunning and deceit. Thus, in 1572 the 'Guisians achieved with cunning and deceit that which they did not achieve by war. ${ }^{63}$ They 'tried to decrown [Henry IV] with force and cunning'.64 Huge Capet, the founder of the monarchy, was 'cunning and experienced in affairs of government, and has liquidated everyone who has since the beginning of his reign seemed suspect to him'. ${ }^{65}$ Louis XI was good in 'simulating and dissimulating' and as such may be regarded the

\footnotetext{
$5^{2}$ 'ambitieusen Dwingeland', Valckenier, Verwerd Europa, 68.

53 'Ambitie', Valckenier, Verwerd Europa, 137.

54 'ambitieuse desseynen', Valckenier, Verwerd Europa, 139.

55 'Heers-sucht en Ambitie', Valckenier, Verwerd Europa, 154.

56 Valckenier, Verwerd Europa, 154.

57 Valckenier, Verwerd Europa, 6 o.

58 'gefingeerde pretext', Valckenier, Verwerd Europa, 53.

59 'op de hoogste trap van sijne Overmacht geklommen zijnde', Valckenier, Verwerd Europa, 186.

6o 'tyrannigen Aart', Valckenier, Verwerd Europa, 371.

61 'dwinglandye', Valckenier, Verwerd Europa, poem in introduction.

62 'ambitieuse Desseynen, Politijke Maximen, Vreemde Intrigues en Kuyperyen aan alle Hoven Van de Christenwerelt', Valckenier, Verwerd Europa, 'Aan den leser'.

63 'de Guisianen met list en bedrog verkreegen 't gene haar het Oorlogsswaard weygerde', Valckenier, Verwerd Europa, 45 .

64 'hoe men hem met geweld en list socht te ontkroonen', Valckenier, Verwerd Europa, 49.

65 'Capet, die listig en ervaaren was in 't stuk van Regeeringe, heeft in 't begin van sijne heerschappye alle van kant geholpen, die hem eenigsins suspect scheenen', Valckenier, Verwerd Europa, 36 .
} 
'founder of the present state of France'.66 'We can see how the French mislead and blind other nations'. ${ }^{67}$ He speaks of 'strange intrigues' 68 and the 'pretext' that France always makes to establish peace. ${ }^{69}$

Valckenier thus consciously employs the universal monarchy discourse that Lisola introduced in his book. For this research, for the sake of methodological focus, we will look at three aspects related to the supposed French aspirations for universal monarchy only, which have come up in the analysis above, namely the suggestion that the French kings are proud, that they are warlike, and that they cannot be trusted in their negotiations. From the analysis of Valckenier's book we can deduce a basic discourse on French universal monarchy built around several clusters of keywords. For the purpose of this chapter I will focus on keywords related to pride, keywords related to warmongering, and keywords related to deceit. Among the first we find heerszucht (lust for rule, dominion), trots/hovaardij (pride), ambitie (ambition), the term universele monarchie (universal monarchy) and opgeblazen (inflated). In the second cluster are words that are related to the warlike nature of the French, such as overwinnen (conquer), jaloezie (jealousy) and oorlog (war). In the third cluster are words related to list (cunning), pretext (pretext) and intrige (intrigue).

\section{Universal Monarchy Discourse in News Sources}

Let us start with an analysis of public news sources, for which I have selected two editions of the Europische Mercurius, a periodical established in 1690 with the purpose of narrating political events in Europe. It appeared twice each year between 1690 and 1756 and was a voluminous edition of up to three or four hundred pages with an overview of international events. It based its information for a large part on newspaper articles. ${ }^{70}$ But the Mercurius also carried the complete texts of primary sources, such as resolutions, peace treaties and diplomatic documents. ${ }^{71}$ In fact the bulk of the Mercurius consisted of such sources, but these were connected through extensive sections of editorial

66 'Simuleren en dissimuleeren', 'waardoor hy geworden de eerste fundateur van den hedendaagsen Staat van Vrankrijk', Valckenier, Verwerd Europa, 41.

67 'Hier uyt sien wy, hoe de Fransche andere Natiën misleyden en verblinden', Valckenier, Verwerd Europa, 60.

68 'intrigues', Valckenier, Verwerd Europa, 217.

69 'pretext', Valckenier, Verwerd Europa, 68.

$70 \quad$ Haks, Vaderland \& Vrede, $196-197$.

71 J.W. Koopmans, 'De Europische Mercurius (1690-1756) getypeerd,' Groniek, 33 (2000), 363. 
comments. The price, probably four guilders, suggests that it was read primarily by the more affluent classes in the Dutch Republic. ${ }^{72}$ The editions of 1709 and 1710 pay attention to the negotiations in Woerden and Geertruidenberg. ${ }^{73}$

The Europische Mercurius, established at the start of the Nine Years' War, was from its inception framed around the anti-French cause, ${ }^{74}$ and it is no surprise that both editions open with references to the war against France, thereby using specific universal monarchy discourse. Peace was to be wished for, the 1709 edition opens, 'but it appears to be impossible as long as the world will stand, and the unjust ambition of kings and other sovereigns does not die away'. ${ }^{75}$ More specifically, the Mercurius referred to 'the French king' who is 'not content with his realm, and wishes to adhere many conquered places ... to his house'. Through the union with Spain he wishes that 'all other high authorities are put on a leash, and must bow to him. ${ }^{76}$ It refers to the 'usurpations' of France, its 'arrogant suppressions' 77 and its 'immoderate lust for dominion. ${ }^{78}$

Precisely the same language is used in the 1710 edition, which opens with the 'unchangeable lust for dominion of the French court,' which keeps to its 'ancient usurpations. ${ }^{79}$ This is the root cause of the fact that chances for peace are slim. ${ }^{80}$ The warlike nature of the French is emphasized: they want 'to make sure the war will end to the glory of the Crown of Lilies's ${ }^{81}$ Their methods are cunning. The author speaks of the 'artifices' of the French court's2 and of of

72 Koopmans, 'De Europische Mercurius,' 363n, 370.

73 Europische Mercurius, behelzende de voornaamste zaken van staat en oorlog, voorgevallen in alle de koningryken en heerschappyen van Europe 20 (1709, 2 vols.) and 21 (1710, 2 vols.).

74 Koopmans, 'De Europische Mercurius'.

75 'dog zulks schynt onmoogelyk zo lange de Waerelt staat, en dat de onregtvaardige Ambitie van Koningen en andere Souverainen niet versterft', Europische Mercurius 20 (1709), 1: 5 .

76 'dat den Franschen Koning niet te vreeden met zyn eigen Ryk, en nog veel ander Geconquesteerde plaatzen....aan zyn Huis zoekt te hegten', 'alle andere Hooge Mogendheden aan den band te leggen, en voor zig te doen buigen', Europische Mercurius 20 (1709), 1: 6.

77 'usurpeeringe', 'hoogmoedige dwinglandyen', Europische Mercurius 20 (1709), 2: 7, 17; 'hoogmoedige dwinglandyen', Europische Mercurius 20 (1709), 2: 7.

78 'onmatige Heerschzugt', Europische Mercurius 20 (1709), 2: 17.

79 'onverzettelyke Heerschzugt van het Fransche Hof', 'verouderde Usurpatien', Europische Mercurius 21 (1710), 1: 6.

8o $\quad$ Europische Mercurius 21 (1710), 1: 6.

81 'en eindelyk den oorlog nog tot Glorie van de Lely Kroon te doen eindigen', Europische Mercurius 21 (1710), 1: 53 .

82 'kunstenaryen van het Fransche Hof', Europische Mercurius 20 (1709), 2: 3,4. 
'evil practices' and 'distrust'. 83 The allies were luckily aware of the 'evil intention' and are guarded against 'such French cunning'. ${ }^{84}$

Having established the ambition, warlike nature and cunning of the French, the author then discusses the negotiations in more detail, within the framework of interpretation already established. 'Let us now see, how cunning the conferences of peace... have ended. ${ }^{85} \mathrm{He}$ concludes with a humorous report about a German print on Geertruidenberg, typically depicting 'a Dutchman plainly clothed in a robe, and a Frenchman with, after the latest fashion, attired with plumes on his hat,' thus juxtaposing French warmongering/pride with Dutch peace-loving/humility. ${ }^{86}$

\section{Universal Monarchy Discourse in Published Government Sources}

The actual analysis of the Geertruidenberg negotiations is not discussed by the author of the Europische Mercurius but related through publishing a ten-page resolution of the States General in response to the breaking off of the negotiations. It is a natural bridge to the second category of sources, then, government sources. So far we may establish that public media such as pamphlets and mercuries were steeped in the universal monarchy discourse, but was the same true for official government sources? These present an interesting category for having to peddle both diplomatic language and popular appeal in cases they were published.

For obvious reasons the language of the resolution, a formal document by a high authority, is different from that of pamphlets and periodicals. It uses very official and factual language to describe the negotiations in detail. Nevertheless, on closer look the same discourse permeates the resolution. ${ }^{87}$ Interestingly, the resolution shows itself to be very aware of its public nature. It is a direct response to a published letter of D'Huxelles and Polignac from July 1710. The letter was also published with sections from the resolution

83 'snoode praktijken', 'mistrouwen', Europische Mercurius 21 (1710), 1: 6.

84 'snood oogmerk', 'listigheden', Europische Mercurius 21 (1710), 1: 53.

85 'Laat ons nu eens gaan bezien, hoe slinks de conferentie van Vreede (met de Fransche Ministers te Geertruidenberg gehouden) afgeloopen is', Europische Mercurius 21 (1710), 2: 134 .

86 'een Hollander eenvoudig gekleed met zyn mantel om, en een Franschman na de mode, gerappierd met pluimen op den hoed', Europische Mercurius 21 (1710), 2: 152.

87 Resolution States General 27 July 1710, reprinted in Europische Mercurius 21 (1710), 2: $140-15^{2}$. 
as a separate pamphlet. ${ }^{88}$ The French negotiators blamed the failure of the Geertruidenberg negotiations on the Dutch, which was, the resolution argues, nothing more than an attempt 'to incite an evil impression among the subjects of England as well as in the state against the government'. ${ }^{89}$ It counters the claim of the French who complain about 'injurious libels' in the Netherlands, which are, after all, 'in this country forbidden with sharp resolutions,' 90 thus implicitly underscoring (if critically) the public performances of the negotiations of the diplomats.

The drift of the resolution is that the French never wanted peace in the first place. The focus of the resolution is on the negotiations so naturally references to the 'intrigue' cluster of key words are more frequent than those to 'war'. The States General complain about the 'fair words' which are only a 'pretext'. For this reason also, Polignac and d'Huxelles have written a letter full of 'insinuations' but 'did not express themselves more clearly'. ${ }^{91}$ This phrase is repeated several times: they want the French to 'explain themselves clearly and transparently' with regard to the preliminaries, a 'clear and transparent explication' from the side of the French, ${ }^{92}$ a binary suggesting the deliberate lack of clarity of the French which presumably aids their cunning. The allies could not live with insecurity or 'content themselves with words and promises' ${ }^{93}$ The resolution speaks of the 'pretexts' to cause 'jealousy'94 and the 'design' to break the negotiations, which in turn can be related to the warlike intentions of France. ${ }^{95}$ After all, France 'has on its own occupied the entire Spanish monarchy, and

$88 \quad$ Knuttel 15896.

89 'om aan de onderdanen zo in Engeland als in den Staat, een quade impressie tegen de Regeringe in te drukken', Resolution States General Europische Mercurius 21 (1710), 2, 149-150.

9o 'dat het publiceren van injurieuze Libellen hier te Lande met scherpe Placcaten verboden is', Resolution States General, Europische Mercurius 21 (1710), 2, 150.

91 'schoone woorden', 'voorgegeven', 'inzimulatien', 'niet klaar expliceerden', Resolution States General, Europische Mercurius 21 (1710), 2, 140-142.

'een klare en duidelyke explicatie', Resolution States General, Europische Mercurius 21 (1710), 2, 144 .

93 'zig te contenteeren met woorden en beloften', Resolution States General, Europische Mercurius 21 (1710), 2, 144 .

94 'gezogte middelen', 'jalousie', Resolution States General, Europische Mercurius 21 (1710), 2,149 .

'dessein', Resolution States General, Europische Mercurius 21 (1710), 2, 149. 
threatens the rest of Europe with similar occupation.96 But with reference to the ambition of France, the resolution states that France attempts to 'reach its design. ${ }^{97}$ It is related to the fact that France has subjected her own subjects to 'long slavery and suppression'.98 Humiliation is a counterpoint to the arrogance of France, who has asked for the protection of God 'with a simulation of humiliation'.99 Combined, this evidence confirms 'how dear the lust to dominate her neighbours' is to France. ${ }^{100}$

\section{Universal Monarchy Discourse in Political Documents and Correspondence}

Even though there is a clear universal monarchy discourse pervading the resolution, the conventions of the genre are obviously different from those of the Europische Mercurius. The bulk of the text is basic, factual and descriptive, but the final part is opiniated. Interestingly, as we have seen, the source itself shows awareness of its public role. The question remains, whether public opinion sources and published official sources such as the resolution are intertextually connected with unpublished and confidential policy sources. That is: is there a sharp divide between 'propagandic' sources and 'real' political sources? For the last category I have selected two kinds of sources. The first one is a policy advice document, a memorial of about twenty folio pages about the negotiations in 1709 and 1710 written by Jacob Surendonck, the secretary of Grand Pensionary Anthonie Heinsius, entitled Remarques op de voorslaegen van vreede die bij Vrankrijk gedaen sijn off gedaen sullen worden ('Remarks on the proposals of peace to be made or made by France'). ${ }^{101}$ The source is important as there are in fact very few policy documents of this kind. There

96 'als dezelve alleen de gansche Spaansche Monarchie heeft geoccupeert, en de rest van Europa voor gelyke occupatien in gevaar gesteld', Resolution States General, Europische Mercurius 21 (1710), 2, 147 .

97 'oogmerk', Resolution States General, Europische Mercurius 21 (1710), 2, 149.

98 'langduurige slavernye en onderdrukkinge', Resolution States General, Europische Mercurius 21 (1710), 2, 150 .

99 'schijn', 'nedrigheit', Resolution States General, Europische Mercurius 21 (1710), 2, 149.

100 'hoe dier haar staat de begeerte om te heerschen over hare nabuuren', Resolution States General, Europische Mercurius 21 (1710), 2, 150.

101 Jacob Surendonck, 'Remarques op de voorslaegen van vreede die bij Vrankrijk gedaen sijn off gedaen sullen worden', March or May 1709, Nationaal Archief (The Hague), Archief Jacob Surendonck, 3.20.57/161. 
are also few records of deliberations of political debates. Thus the memorial gives us an in-depth view of the secret considerations of the political elite. However, Surendonck is extremely critical of France and may not be a 'typical' official. Surendonck is highly critical of the French proposals and is convinced that they have been offered only because France is severely weakened and is using the talks to divide the allies and gain time. France will use the peace to regain strength and start another war, 'especially when France remains to be governed by such ministers and maxims as it has been now for more than half a century,' he suggests, thus underscoring the conventional time frame of universal monarchy discourse. ${ }^{102}$

Surendonck's memorial is steeped in universal monarchy discourse and exhibits the three elements we distinguished in the other sources: pride, war and intrigue. Surendonck frequently alludes to the pride of France, the 'despotic and arbitrary power' of the French king who is suppressing his subjects and has to 'master absolutely' their possessions. He is trying to 'dominate' the Allies. ${ }^{103}$ Surendonck complains about the 'proud, faithless and godless enemy' and its 'tyrannical and doomed suppression which is unbearable for the subjects, as well as dangerous for its neighbours. ${ }^{104}$ Should the allies defeat France, it would be 'a just retribution of divine wrath, because of the unbearable pride and terrible persecution, destruction and cruelty.105

In addition to pride and dominion, Surendonck frequently refers to the inherently warlike nature of France. He argues that the French will try to use the pretext that they are trying to 'conserve the peace and prevent a new war'. But the French 'design' is to 'concoct a new war with greater advantage.'106 Surendonck also refers to the warlike nature of the French nobility, thereby almost directly quoting the basic text of Valckenier's Verwerd Europa: 'it is known from ancient times that the French nation, especially the nobility,

102 'Soo wanneer Vrankrijk, door sulke ministers en maximen bij Continuatie sal worden geregeert, als nu meer als een halve Eeuw herwaerts geschiet is.', Surendonck, 'Remarques,' 2.

103 'despotique en arbitraire magt', 'absoluijt meester', 'overheerschen', Surendonck, 'Remarques,' 11.

104 'trotsen, trouwloosen en godloosen Vijand', 'Tyrannique en heijloose dwingelandij, die soo ondraeglijk is voor de onderdanen, als gevaerlijk voor de naebuijren', Surendonck, 'Remarques,' 12.

105 'als een regtveerdige vergeldinge van de goddelijke wrake, wegens die ondragelijke trotsheijt en gruwelijke vervolginge, verwoestinge en wreetheden', Surendonck, 'Remarques,' 14. Surendonck refers to the prophecy in Isaiah 33:1.

106 'de gemaekte vrede te conserveren en een nieuwe Oorlog te voorkomen', 'om daer uijt ter gelegener tijt met meerder avantagie een nieuwe oorlog te smeden', Surendonck, 'Remarques,' 7 . 
is of a restless and warmongering nature'.107 He fears the French 'despotic overmacht'.108

Surendonck also observes the intrigues of the French, arguing that in the 'last peace negotiations they have used the same language and discourse to facilitate the peace, but that we have always been very much deceived.'. ${ }^{109} \mathrm{He}$ speaks of 'pretext,' 'sinister practices and intrigues' the French employ to use the peace negotiations to prepare a new war. ${ }^{110}$

It is difficult to say whether Surendonck's memorial was typical as there are few comparable sources and Surendonck was notoriously anti-France and suspicious of its policy. Nevertheless, the memorial does underscore the fact that such language was actually used in policy documents, even if the prevalence cannot be measured by this one example. This can be done, however, by studying a last primary source, namely diplomatic correspondence of Anthonie Heinsius, which, unlike the memorial, contains an abundance of material. ${ }^{111}$

Several constraints hamper an analysis of the correspondence. First of all, most of the letters are matter of fact and refer to operational issues. They deal with troop movements, reports of the arrivals and departures of diplomats, and reports of affairs at foreign courts. There is disappointingly little reflection upon issues of policy. Moreover, most of the letters are incoming. Heinsius received about twenty thousand letters between 1702 and 1720 (the years covered by the published correspondence), but wrote relatively few letters in reply, and those he wrote were curt. There is another matter to be considered, namely that the actual negotiations between Buys and Van der Dussen and the French diplomats were conducted in utter secrecy, and the negotiators were not inclined to entrust their contents or their thoughts to paper in detail. Thus, a typical quote from a letter written to Heinsius by Buys and Van der Dussen from Geertruidenberg where the negotiations took place reads: 'we

107 'Sijnde van Outs bekent, dat de fransse natie, en in bijsonder de Adel, is van een onrustigen, en oorlogssugtigen Aert en inborst', Surendonck, 'Remarques', 7. Valckenier wrote that 'the French from ancients times have been from such a restless and moveable spirit ... that they do not live in peace, but are always inclined to war'. Cf. footnote 31.

108 'despotique overmagt', Surendonck, 'Remarques', 9.

109 'dat men in alle de voorige Vredehandelinge altoos die selve taelen en discoursen gevoert heeft, om de vreede te faciliteren, maer dat men sig telkens daer omtrent deerlijk bedrogen heeft bevonden', Surendonck, 'Remarques', 7.

110 'oogmerk', 'sinistre practijcque en intrigieus', Surendonck, 'Remarques', 7.

111 This can be done through the extensive De Briefwisseling van Anthonie Heinsius 1702-1720, ed. A.J. Veenendaal (The Hague: Nijhoff, 1976-2001), and The Correspondence of John Churchill, First Duke of Marlborough, and Anthonie Heinsius, Grand Pensionary of Holland 1701-1711, ed. B. van 't Hoff (The Hague: Nijhoff, 1951). 
have arrived yesterday in the early morning in Moerdijk and have met Marshal d'Huxelles and Prior de Polignac at around $5 \mathrm{pm}$... we will give you and extensive report orally' after our return. ${ }^{12}$ However, a number of correspondents were informed in broad lines of the contents of the negotiations and reflected upon these.

Interestingly, there are several direct references to the basic source we have selected. Albert van der Meer, envoy in Turin, wrote that France will recover and probably wage war again because it is 'an active and restless nation,' thereby using almost precisely the same phrase as Surendonck and Valckenier to point to the warlike nature of France. ${ }^{113}$ More specific was Clignet, the postmaster of Utrecht. In a letter to Heinsius he referred to the necessity of curbing French ambitions, which, he writes, are all well-known from 'Lisola, whose memory cannot be praised enough, in his Bouclier D'Estat Et De Justice anno 1677'.114

Basic distrust permeates the correspondence, as for instance displayed in a letter by Anthonie Heinsius to the Duke of Marlborough, expressing the expectation that the French would use the negotiations in 1709 to divide the Allies. ${ }^{115}$ In 1710 he wrote to Marlborough about the start of the negotiations that Van der Dussen and Buys were finding out 'le fond du coeur de France.' ${ }^{16}$ 'Je ne suis pas tout à fait convaincu de la sincérité de la France dans la négotiation présente,'117 he wrote, the same phrase Marlborough himself used ('I see the French ministers continue in their insinserity, which I do not wonder att [sic]'). ${ }^{118}$

There are a number of references to France's arrogance and greatness. Referring to the negotiation between Rouillé and Buys in 1709, Jacob Hop wrote about 'the great overmacht of France and... her pernicious ways of acting.'119 Van der Meer complained about France's 'ambitious designs.'120 The design of France is frequently alluded to. Robert Goes, envoy in Copenhagen, wrote

112 'aan dezelve van alles omstandig rapport te doen en verders mondeling te verzekeren ...', Buys and Van der Dussen to Heinsius, 10 March 1710. See also Buys and Van der Dussen to Heinsius 22 March 1710, 8 April 1710. In: De Briefwisseling, ed. Veenendaal, 10: 159, 194, 239.

113 'een active en inquiète natie sijnde', Van der Meer to Heinsius, 29 March 1709, in Briefwisseling, 8, ed. Veenendaal: 393 .

114 Clignet to Heinsius 16 June 1709, De Briefwisseling, 8, ed. Veenendaal: 6o9.

115 Heinsius to Marlborough 26 March 1709, Correspondence, ed. Van 't Hoff: 432.

116 Heinsius to Marlborough, 23 April 1710, Correspondence, ed. Van 't Hoff: 485.

117 Heinsius to Marlborough, 28 May 1710, Correspondence, ed. Van 't Hoff: 494.

118 Marlborough to Heinsius, 1 June 1710, Correspondence, ed. Van 't Hoff: 494.

119 'groote overmacht als Vranckrijck en tegens haere pernitieuse manieren', Hop to Heinsius, 30 March 1709, De Briefwisseling, 8, ed. Veenendaal: 396.

120 'ambitieuse dessijnen', Van der Meer to Heinsius, 20 April 1709, Briefwisseling, 8, ed. Veenendaal: 451 . 
in June 1710 about the French 'pretenses' to the Spanish monarchy. ${ }^{121}$ Marinus van Vrijbergen, the Dutch ambassador in London, referring to a 1708 military operation, brought up the 'arrogance in this work of the French'. ${ }^{122}$ The French are seen, as another observer wrote in January 1709 , as 'the suppressor, our great enemy'. ${ }^{123}$ Francisco Schonenberg, the Dutch envoy in Lisbon, in a letter of August 1704, referred to French 'usurpation and tyranny' with regard to her expansion in Spain, Italy and the Netherlands. ${ }^{124}$ Heinsius as well cited 'la tiranie de nos aversaires.' 125 The negotiations are difficult precisely because the enemy is strong and arrogant. Heinsius, who writes to Vrijbergen in November 1710, after the negotiations in Geertruidenberg have failed, that the 'French are inflated by their good fortunes and will be intractable concerning a good peace.'.126 To Count Rechteren he wrote in September that a military victory the French have just achieved 'has inflated them to the extent that they have broken off all negotiations.'127

Interestingly, the agent Helvetius reported that the French ambassadors were actually shocked by the arrogant manners of the Dutch negotiators, especially Van der Dussen, who 'has a manner which approaches brutality impertinence .... and that on top of that he is arrogant and insolent and judges nothing of value.'128 This may have something to do with the fact that the Dutch were supremely confident, being assured that 'the French are in dire straits and inclined to make peace.129 Many observers were therefore very optimistic about chances for peace, despite the basic distrust of the Dutch.

\footnotetext{
121 'pretensiën', Goes to Heinsius, 21 June 1710, Briefwisseling, 10, ed. Veenendaal: 460.

122 'd'arrogantie in dit werck der Franssen', Vrijbergen to Heinsius, 10 April 1708, Briefwisseling, 7, ed. Veenendaal: 211.

123 'dwinglander onse overgroote vijandt', Regulus to Heinsius, 6 January 1709, Briefwisseling, 8, ed. Veenendaal: 180.

124 'usurpatie en tyrannie', Schonenberg to Heinsius, 18 August 1704, Briefwisseling, 3, ed. Veenendaal: 284 .

125 Heinsius to Goslinga, 21 August 1709, Briefwisseling, 9, ed. Veenendaal: 186.

126 'de Fransen door voorspoet opgeblaesen sijnde, sullen ontrent een goede vrede intractabel werden', Heinsius to Vrijbergen, 30 December 1710, Briefwisseling, 11, ed. Veenendaal: 458 .

127 'heeft haer evenwel soo opgeblaesen gemaeckt, dat genoegsaem alle negotiatie weer hebben afgebroocken', Heinsius to Rechteren, 13 September 1709, Briefwisseling, 9, ed. Veenendaal: 250 .

128 'd'une manière dure, qui aproche de la brutalité... dat hij daerenbove arrogant en insolent is en niets van waerde oordeelt', Wassenaar to Heinsius, 13 May 1710, Briefwisseling, 10, ed. Veenendaal: 337 .

129 'de Franse seer in de noot waeren ende genegen sijn om vrede te maken', Heinsius to Buys, 17 May 1710, Briefwisseling, 10, ed. Veenendaal: 353 .
} 
The warlike nature of the French is also emphasized. Jacob Hop, a senior administrator in the temporary government of the Spanish Netherlands, mentioned the French 'lust to penetrate up until our border and disturb us into the heart of the country'. This 'lust' is illustrated when he writes that after the Peace of Nijmegen, 'every time she lusted she entered the territory of the Spanish Netherlands' with soldiers. ${ }^{130} \mathrm{He}$ also referred to the danger to Europe of 'the great overmacht of France and... her pernicious manners of acting and persistent use of force. ${ }^{131}$ Van der Meer spoke of the 'overmacht' of France. ${ }^{132}$ Heinsius uses the same word, 'overmacht', to describe the position of the French. ${ }^{133}$

As one might expect from reflections upon the talks, they mostly dealt with comments on the actual negotiations and thus, within our chosen selection, the cluster of keywords related to intrigue. Heinsius was not sure 'whether the French have peace on their minds or not'. ${ }^{134}$ Van den Bergh was in doubt about the 'designs of the French' and therefore the negotiations had to proceed with 'extreme precaution., ${ }^{135}$ Van der Meer stressed the necessity to guard against 'her surprises or designs.'136 The terms most often used are thus connected to the style of negotiating. Vrijbergen wrote to Heinsius in connection with the negotiations in 1709 about the 'usual chicanery' of the French. ${ }^{137}$ The Utrecht nobleman Renswoude complained about the 'effrontery' of the French to raise the demands in the negotiations in April 1709. ${ }^{138}$ The Holland nobleman Wassenaer referred to the frequent 'difficulties' the French made in the

130 'telkens als 't haer lust tot op onse frontieren door te boren en ons tot in 't hert van 't land te ontrusten', 'als 't haer luste op den bodem van de Spaensche Nederlanden quam', Hop to Heinsius, 30 March 1709, Briefwisseling, 8, ed. Veenendaal: 396.

131 'tegens soo groote overmacht als Vranckrijck en tegens haere pernitieuse manieren van doen en genoechsaem gestadige geweldenaerijen, sijn geweest', Hop to Heinsius, 30 March 1709, Briefwisseling, 8, ed. Veenendaal: 396.

132 'overmaght', Van der Meer to Heinsius, 13 March 1709, Briefwisseling, 8, ed. Veenendaal: 334 .

133 'overmacht', Heinsius to Vrijbergen, 7 November 1710, Briefwisseling, 11, ed. Veenendaal: 335 .

134 'off de Fransen in 't zin hebben de vreede te maken off niet', Heinsius to Rechteren, 11 June 1709, Briefwisseling, 8, ed. Veenendaal: 587 .

135 'desseinen van de France', 'd'uyterste precautie', Heinsius to Van de Bergh, 12 June 1709, Briefwisseling, 8, ed. Veenendaal: 594.

136 'surprises of dessijnen', Van der Meer to Heinsius, 13 March 1709, Briefwisseling, 8, ed. Veenendaal: 335 .

137 'gewoolijcke chicanes', Van de Bergh to Heinsius, 28 March 1709, Briefwisseling, 8, ed. Veenendaal: 386 .

138 'd'effronterie', Renswoude to Heinsius, 14 April 1709, Briefwisseling, 8, ed. Veenendaal: 439. 
negotiations. ${ }^{139}$ Heinsius confided to Count Rechteren about his 'fear that her [the French] design is to make diversion and division among the allies.. ${ }^{140}$ Van der Meer noted the 'cunning propositions of the enemies. ${ }^{141}$ The deputies for foreign affairs concluded in June 1709, after the broken negotiation, that there ought to be a firm reply to the 'French conceits.' ${ }^{42}$ The States General cited the 'fraudulous conduct of France.'143

One central key word is used surprisingly rarely. Heinsius, towards the end of the Geertruidenberg negotiations, referred to the likelihood that France would, 'more than ever before be able to achieve universal monarchy,'144 and in December he again observed that 'the French proceed with giant steps towards universal monarchy.'.145 These are the only two explicit references I found to the term 'universal monarchy' in the extensive Heinsius correspondence.

\section{Conclusion}

We may tentatively conclude that the three categories of sources share a vocabulary pointing to a pervasive universal monarchy discourse. In addition to a few close paraphrases and direct references to Lisola and Valckenier, we have distinguished a number of key words spread over three clusters related to pride, warlike nature and intrigue. To dominate (heersen, overheersen) is widely shared in all sources except for the correspondence of Heinsius. References to 'tyranny' likewise appear in all sources except for the Resolution of the States General. 'Dwingelandij' (suppression) appears in all sources except in the Resolution. 'Arrogant' is used in Valckenier, the Europische Mercurius and the Heinsius correspondence. Of course, the resolution and the memorial are relatively short sources, and there is no reason to suggest that studying more sources would not yield further results. Moreover, when the analysis is broadened to intertextual clusters of keywords, more connections can be made. For

139 'difficulteiten', Wassenaar to Heinsius, 8 June 1709, Briefwisseling, 8, ed. Veenendaal: 583.

140 'om tussen de geallieerden een diversie ende scheuring te maken', Heinsius to Rechteren, 22 April 1710, Briefwisseling, 10, ed. Veenendaal: 271.

141 'listige propositiën der vijanden', Van der Meer to Heinsius, 12 October 1709, Briefwisseling, 9, ed. Veenendaal: 351.

142 'Franse bedriegerijen', quoted in Stork-Penning, Het grote werk, 304.

143 'frauduleuse conduites', quoted in Stork-Penning, Het grote werk, 309.

144 'ende licht eer als ooyt tevooren tot de universele monarchie geraken', Heinsius to Vrijbergen, 1 July 1710, Briefwisseling, 10, ed. Veenendaal: 495.

145 'gaen de Fransen weer haest voort met groote passen na de universele monarchie', Heinsius to Vrijbergen, 30 December 1710, Briefwisseling, 11, ed. Veenendaal: 459. 
instance, rather than 'arrogance' Surendonck speaks of 'ondraaglijke trotsheijt' ('unbearable pride'). 'Intrigues' is used by the Europische Mercurius, Valckenier and Surendonck. 'List' or 'listigheid' (cunning) can be found in the Europische Mercurius and the Heinsius correspondence. Valckenier actually used the reference 'Fransche listen' as a key concept in his index. ${ }^{146}$ 'Usurpor' appears in all sources but Surendonck and the Resolution. Allusions to the French design ('desseign' or 'oogmerck') appear in all sources. 'Overmacht' (dominance) appears in all sources except the Resolution and the Europische Mercurius. The key phrase 'universal monarchy' appears in all sources except the Resolution.

The research has thus shown the viability of looking for intertextual connections; obviously, universal monarchy discourse pervaded all three categories of sources. At the same time, it is clear that it was only thinly spread throughout diplomatic correspondence and much more prevalent in the published sources. There are clear reasons for the relative dearth of universal monarchy discourse in political correspondence, which was often curt and often omitted the substance of discussions. Nevertheless, even if this is so, intertextual connections can be established only if they are actually there. Although this case study indicates that universal monarchy discourse is spread throughout the categories of sources and that a shared discourse was used, clearly the terminology and the frequency of the keywords are genre specific. Moreover, Lene Hansen argued that a discourse must be widely spread throughout a large number of sources for there to be a 'basic discourse.'147 In this sense, the case has only partially been proven, and the conclusion is therefore indicative rather than conclusive.

A question remains regarding the actual performative power of this universal monarchy discourse. The language used can be seen as a reflection upon the reality, but arguably the diplomatic discourse created that very same reality. The observations about French pride were self-affirming, and prejudice was inherent in the language the diplomats adopted, a language, we have seen, which was intertextually connected to the basic discourse on Universal Monarchy. In this view, and in conclusion to my chapter, I suggest that the failure of the peace negotiations was caused not so much by a stalemate or French unreliability but, to a substantial degree, by Dutch prejudice regarding French pride, warmongering and cunning. Although this cannot be proven, the fact that the negotiations foundered on mistrust while the Dutch widely used

146 Valckenier, Het Verwerd Europa, index (n.p.).

147 Hansen, Security as practice, 52. 
a discourse on French unreliability strongly points in this direction. Universal monarchy discourse, intertextually linked to popular sources cultivating antiFrench sentiments, pervaded Dutch diplomatic sources as well as the news and may therefore have influenced the peace negotiations more than has been suggested in the past. 